\title{
THE MORAL OBLIGATION TO PERFORM CONTRACTS: SOME PRELIMINARY THOUGHTS*
}

\author{
LA OBLIGACIÓN MORAL DE CUMPLIR LOS CONTRATOS: \\ ALGUNAS CONSIDERACIONES PRELIMINARES
}

\author{
Brian H. BIX ${ }^{* *}$
}

\section{Resumen:}

¿Tiene uno la obligación de cumplir sus contratos? Para muchas personas, la tendencia inicial sería contestar que "sí", debido a la fuerte relación entre contratos y promesas, aunada con la convicción de que, en igualdad de condiciones, uno debe cumplir sus promesas. Sin embargo, un análisis más detenido de la pregunta sobre la obligación moral de cumplir los contratos, plantea complicaciones y dudas. En primer lugar, muchos han cuestionado la relación entre el contrato y las promesas, argumentando que los contratos y el derecho contractual se entienden mejor de alguna otra manera. En segundo lugar, muchos suelen pensar que nuestro deber de cumplir con nuestros acuerdos varía en función de la medida en que la decisión de celebrar el acuerdo se haya desviado del consentimiento óptimo, o de los hechos sobre la equidad de la relación de fondo y la sociedad en general.

Parece ser que la obligación de cumplir un contrato varía según las circunstancias. La injusticia en la sociedad, en la relación subyacente, en la negociación del acuerdo, o en las condiciones del mismo iría en contra de dicha obligación moral. También queda la pregunta de cuál sería el contenido de la obligación de cumplir el contrato, si es que existe. La mayoría de nosotros supondría que es una presunta obligación real por llevar a cabo, pero algunos sostendrían que se trata simplemente de una obligación de cumplir o

Artículo recibido el 20 de enero de 2020 y aceptado para su publicación el 6 de agosto de 2020.

${ }^{* *}$ Frederick W. Thomas Professor of Law and Philosophy, University of Minnesota, mail: bixxx002@umn.edu, ORCID: https://orcid.org/0000-0001-6644-7241. An earlier version of this article was presented at a Workshop at the Instituto de Investigaciones Jurídicas de la UNAM. I am grateful for the comments and suggestions made by those attending. 
BRIAN H. BIX

pagar daños y perjuicios. Aunque el pago puntual de los daños y perjuicios - sin impugnar el incumplimiento, reclamar una cantidad menor de daños o amenazar con una litigación prolongada y costosa- ya sería un avance importante en las actuales prácticas comerciales habituales.

\section{Palabras clave:}

Contrato, promesa, obligación moral de acatar la ley, David Hume, consentimiento, justicia.

\section{Abstract:}

Does one have an obligation to keep one's contracts? For many people, the initial inclination would be to answer "yes," based on the strong association of contracts and promises, combined with the belief that, other things being equal, one should keep one's promises. A closer examination of the question of the moral obligation to keep one's contracts, however, raises complications and doubts. First, many have questioned the connection between contract and promises, arguing that contracts and contract law are best understood in some other way. Second, many are inclined to think that our duty to keep our agreements varies with how far the decision to enter the agreement deviated from optimal consent, or with facts about the fairness of the background relationship and society generally.

It seems likely that one's obligation to keep a contract will vary with its circumstances. Injustice in society, in the underlying relationship, in the negotiation of the agreement, or in the agreement's terms would work against any such moral obligation. There also remains a question of what the content of the obligation to keep one's contract would be, if there is one. Most of us would assume that it is a presumptive obligation actually to perform, but some would argue merely for an obligation to perform or pay damages. Though the prompt payment of damages - without disputing the breach, claiming a lower amount of damages, or threatening protracted and expensive litigation - would already be a significant advance on current common commercial practices.

\section{Keywords:}

Contract, Promise, Moral Obligation to Obey the Law, David Hume, Consent, Justice. 
THE MORAL OBLIGATION TO PERFORM CONTRACTS...

Summary: I. Introduction. II. An Overview of the Literature on the Obligation to Obey the Law. III. The Relevance of Contract Theory. IV. Consent and Obligation. V. Corrective Justice, Compensation and Distributive Justice. VI. Keeping One's Contracts. VII. Conclusion. VIII. References.

\section{INTRODUCTION}

There is a well-established literature about whether, when, or to what extent citizens have a moral obligation to obey the law. ${ }^{1}$ That discussion looks at various possible justifications for a prima facie moral obligation; the proffered justifications range across argument based on consequences, consent, gratitude, fair play/reciprocity, and the role of government in distributing benefits and burdens across society. ${ }^{2}$ For a long time, the consensus was that citizens $d o$ have such a moral obligation, at least for generally just regimes. ${ }^{3}$ In recent years, scholars have raised questions about that consensus, and many now argue that there is no such general moral obligation to obey, and that moral analysis needs to be on a more individualized basis, considering the moral obligations of certain citizens to obey particular laws.

The literature regarding the moral obligation to obey (or comply with $^{4}$ ) particular categories of obligations is significantly less well

1 See, e.g., M. B. E. Smith, "Is There a Prima Facie Obligation to Obey the Law?", 82 Yale Law Journal 950

(1973); William A. Edmundson (ed), The Duty to Obey the Law: Selected Philosophical Readings (Rowman \& Littlefield, 1999); Christopher Heath Wellman \& A. John Simmons, Is There a Duty to Obey the Law? (Cambridge 2005); Joseph Raz, Ethics in the Public Domain 325-338 (Oxford 1994).

2 Smith, supra note 2, at 953-969.

3 See id. at 950.

4 Where "obedience" means acting in a certain way because the law says so, while "compliance" means acting as a legal rule prescribes, but motivated by reasons other than the rule. See, e.g., Donald H. Regan, "Reasons, Authority, and the 
developed. There is some discussion in connection with criminal law (much of it by critical race theorists ${ }^{5}$ ), but there appears to be little in connection with private law. With criminal law, the connection with the general debate about the moral obligation to obey the law seems more straightforward: when the law commands us to do or not do something, do we have a moral obligation to obey (or comply with) those commands. With private law, the analysis will inevitably be different, as legal rules here are not best understood as commands. While legal rules in this area are certainly intended to affect behavior, they are generally not direct commands to do or not do things, so the analysis of our moral obligation will inevitably look different.

In this article, I will examine whether and when there is a moral obligation to perform one's contractual obligations. Part I offers a brief overview of the debate about the moral obligation to obey the law. Part II considers the connection between contract theory and a moral obligation to perform contracts. Part III turns to the role of absent or imperfect contractual consent in the evaluation of one's moral obligation. Part IV looks at the connection between corrective justice (and its analogues) and distributive justice. And Part V looks at what is meant by "keeping one's contracts," before concluding.

\section{AN OVERVIEW OF THE Literature ON THE OBLigation TO OBEY THE LAW}

There is a large and long-standing literature (going back at least to Plato's Crito and Sophocles' Antigone) regarding whether and when there is a moral obligation to obey the law. There is obviously not

Meaning of 'Obey': Further Thoughts on Raz and Obedience to Law," 3 Canadian Journal of Law \& Jurisprudence 3, 15 (1990).

5 See, e.g., Regina Austin, '“The Black Community,' Its Lawbreakers, and a Politics of Identification," 65 Southern California Law Review 1769 (1992); Paul Butler, "Racially Based Jury Nullification: Black Power in the Criminal Justice System," 105 Yale Law Journal 677 (1995); Ekow N. Yankah, 'Whose Burden to Bear? Privilege, Lawbreaking and Race', Criminal Law and Philosophy (forthcoming, $2019<\mathrm{https}$ // link.springer.com/article/10.1007/s11572-019-09503-x> 
THE MORAL OBLIGATION TO PERFORM CONTRACTS...

sufficient space here to do justice to that extensive discussion, ${ }^{6}$ but it would be useful to the present question to offer a brief overview.

First, even those who argue that there is a moral obligation to obey the law generally hold (with some exceptions ${ }^{7}$ ) that this is true only for generally just legal systems, and that the moral obligation in question is presumptive and thus defeasible. Second, even those who deny that there is a general moral obligation to obey the law will concede that there are often moral obligations to act consistently with what the law prescribes, because legal prescriptions often track moral prescriptions. However, the argument would go, the reason one should not murder, rob, or kidnap is due to moral (and also prudential) reasons that would apply whether these actions were illegal or not.

Those who argue for a moral obligation to obey often focus on actions, choices, or inactions which, they argue, constitute consent to obey the law. The attention is generally on voting, accepting state benefits, or refusing to move out of the jurisdiction. The claim is that by casting a ballot, one has implicitly affirmed the law that results from the elected government, or that not leaving the country is a way of showing that one approves of the community's rules. ${ }^{8}$ Those who deny a moral obligation to obey cast doubt on whether so much

6 See sources cited supra note 2.

7 Thomas Hobbes in his Leviathan appears to be one such exception. See infra note 13 and accompanying text.

8 One is reminded of the bumper sticker that was common in the United States in the 1960s, in response to the anti-War and Civil Rights protests: "America: Love It or Leave It!" One can see the kernel of the same argument, and the consent argument generally, in Plato's "The Crito". Plato has Socrates describing "The Laws" as stating:

"[B]y giving leave to any Athenian who wishes, that when he had been admitted to the rights of manhood and sees things in the City and its Laws which do not please him, he may take what is his and go either to one of our colonies or a foreign land.... But whoever among you stays, recognizing the way we render judgment and govern other affairs of the City, to him at that point we say that by his action he has entered agreement with us to do as we bid."."

Plato, 'The Crito', 51d-e, in Plato, The Dialogues of Plato (R. E. Allen trans.), vol. 1, 117-129, at 127. 
moral weight can be placed on ambiguous actions, ${ }^{9}$ and whether, even if these actions do entail moral duties, these can extend to even relatively trivial laws or circumstances, where disobedience will neither harm others nor undermine a generally just legal system.

There is a related argument, based on gratitude. The gratitude argument is, roughly speaking, that citizens "owe" obedience to the state (at least for governments sufficiently fair and just that they provide services and do not oppress the citizens), in return for all the benefits received (police protection, fire protection, national security, public education, infrastructure, the legal system, etc.) ${ }^{10}$ Critics question the extent to which gratitude is appropriate if benefits are not asked for, or if the giver benefits from the actions. Additionally, critics wonder if the giver of a benefit has any right to set the terms of gratitude, or whether "obedience to all laws" is more than the state has reason to expect by way of gratitude for its actions. ${ }^{11}$

One sometimes hears consequentialist arguments for the obligation to obey the law. The best-known example is that of Thomas Hobbes, who argued for an obligation to obey on the basis that the alternative to obedience was chaos, the state of nature, the war or all against all. ${ }^{12}$ (Hobbes' view of the obligation to obey is broad, and does not depend on the government's being generally just, but it is not absolute. Under Hobbes' view, citizens retain the right to disobey the sovereign to defend their own lives, or if the sovereign has failed to keep its end of the social contract by not maintaining civil peace.)

A somewhat different argument sometimes offered for an obligation to obey the law is based on "fair play." This argument is differ-

9 There is, of course, the substantial (and mostly critical) literature about John Locke's idea of "tacit consent." See John Locke, Two Treatises of Government (P. Laslett (ed.), Cambridge: Cambridge University Press, 1988 [1689]), §2.120; Alex Tuckness, "Locke’s Political Philosophy" (2016) §4, in Edward N. Zalta (ed.), Stanford Encyclopedia of Philosophy <https://plato.stanford.edu/entries/locke-political/>

10 Once again, an early version of this argument can be found in Plato. Plato, supra note 9, 50d-e, 51d, at 125, 126.

11 See Smith, supra note 2, at 953-954.

12 Thomas Hobbes, Leviathan (Richard Tuck, ed., Cambridge University Press 1998) [1651], ch. 20, at 144-145. 
ent, not least in the way that the purported duty is owed to fellow citizens, not to the state. The idea is that society is a joint project, in which all make sacrifices and gain benefits, and for individuals to take the benefits without making their share of sacrifices is a wrong done to other members of the joint project. ${ }^{13}$ A skeptic of this approach might suggest that if a particular illegal action did not undermine society (perhaps because it was morally trivial, and was not seen by impressionable observers) and did not directly harm any other individual, it is unclear on what ground one's fellow citizens could justly complain. ${ }^{14}$

To the view that one has, at most, a legal obligation to obey (or at least comply with) some legal rules, but not all of them (even in a generally just legal system), supporters of a general moral obligation argue that legal systems are seamless webs, that burdens and benefits are distributed across persons and across topics. Additionally, the argument goes, a theory that encourages citizens to pick and choose when they think they have a moral obligation to obey invites inevitably error-prone and self-serving choices. ${ }^{15}$

What if one concludes that there is an obligation to obey the law (even if only a presumptive obligation, and only for generally just legal systems)? Would it then follow that one has on obligation to keep contracts? As already noted, the structure of the analysis appears to differ. Most obviously, "obeying" laws already seems different from "keeping" contracts. Our legal system ${ }^{16}$ does not require people to perform contracts, the way that it requires them not to steal or to pay a certain percentage of their income to the government. As will be discussed in Section V, the law's message on contracts is more along the lines of "either perform or pay damages." Generally speaking, one is not jailed, or even fined, for failing to perform one's contracts. In American contract law, damages are meant to be compensatory, not

13 See Smith, supra note 2, at 954-958.

14 See id. at 958.

15 See, e.g., John Finnis, 'Law as Co-ordination' (1989) 2 Ratio Juris 97.

16 The text is speaking here about the American legal system. It is also true of a number of other legal systems with which I am familiar, but I certainly make no claim to speak about all legal systems. 
punitive. And the obligation to pay compensation generally does not require on the existence of "fault," nor does it vary with the level of fault.

As will be seen, the relationship between one's views on the general moral obligation to obey the law and one's views on the moral obligation to keep one's contracts is necessarily complex. As one moves the subject from the whole legal system (and every legal rule promulgated) to the smaller focus of agreements, the considerations change, not least in the starting assumption that one has consented to each of one's contractual agreements in a way that one has not to each of the legal system's rules. More on this below.

\section{The RELEVANCE of Contract Theory}

Contract law theory (and theories of other doctrinal areas of law) are meant to "explain" the law, to show its essence. Thus, different contract law theories present a different picture of what is going on in the practice of making contracts and the practice of enforcing them. It then seems reasonable to ask whether one's choice of the "correct" or "best" theory of contract law might have implications for the analysis regarding the moral obligation to keep contracts.

For example, if contracts are essentially promises, ${ }^{17}$ it would seem reasonable to note the (presumptive) immorality of breaking one's promise. Or if contracts are essentially about the creation of reasonable reliance in other parties, ${ }^{18}$ it might seem reasonable to note the (presumptive) immorality of acting contrary to such reasonable reliance. On the other hand, if contract rules are just about maximizing wealth or preference satisfaction, ${ }^{19}$ the (im)moral force of not performing as contractually obligated is less clear, or at least less powerful.

17 See, e.g., Charles Fried, Contract as Promise (2nd ed., Oxford, 2015); Seana Valentine Shiffrin, "Is a Contract a Promise?," in Andrei Marmor (ed), The Routledge Companion to Philosophy of Law (Routledge 2012) 241-257.

18 Cf. Grant Gilmore, The Death of Contract (Ronald K. L. Collins, ed., Ohio State University Press 1995)

19 See, e.g., Richard A. Posner, Economic Analysis of Law 95-158 (9th ed., 2014) 
THE MORAL OBLIGATION TO PERFORM CONTRACTS...

That last point may be too quick. One could easily imagine a rule utilitarian approach, under which legal rules in general, and contract doctrines in particular, are chosen - or should be chosen- on the basis that these are the principles which, if followed, will generally maximize collective utility. All of this assumes, of course, that rule utilitarianism is the best approach for matters of policy or morality, and that, of course, is highly contested. And there is an obvious twist to consider: that the best approach for lawmakers in constructing a legal system and promulgating legal rules may not necessarily be the best approach for individuals responding to legal rules. Even within a rubric of rule utilitarianism, and even assuming that lawmakers have promulgated the rules and doctrines which will work best to maximize utility, it does not follow that a rule utilitarian citizen should adopt the rules, "do as the law prescribes" or "keep one's (valid) contracts".

In thinking about how contract law, qua promise or qua consent, might bind us, it might be instructive to recall David Hume's wellknown critique of social contract theories of government. ${ }^{20}$ One part of Hume's critique was that the legitimacy of government cannot be based on the consent of the governed or the promises of the governed, because allegiance to government and fidelity to promises are grounded in the same way, and if one is problematic than so is the other. Hume considers three possible grounds for moral obligation: the moral obligation to do what one has consented to, the moral obligation to do what one has promised to do, and the moral obligation of allegiance to government and law. Hume argues that all three are justified (if they are justified) by social utility.

(The point of the present discussion is not that Hume is necessarily correct on these judgments -- though one should not casually dismiss views offered by a thinker of his stature. The point is that analysis in the present topic may quickly bring us to difficult foundational questions, where there remains significant controversy. There are substantial literatures on whether and when we have moral obli-

20 See David Hume, Moral Philosophy (Geoffrey Sayre-McCord, ed., Indianapolis: Hackett 2006), pp. 361-375 ("Of the Original Contract"); see also Jeffrie G. Murphy, 'Hume and Kant on the Social Contract', 33 Philosophical Studies 65-79 (1978). 
gations based on consent, promise, or agreement. ${ }^{21}$ And it may be that one cannot take a view on the (relatively speaking) small question of an obligation to keep one's contracts without taking a position on those more foundational questions.)

Returning to the inquiry about the connection between contract theory and one's obligation to keep one's contracts, it should be added that if one is skeptical about contract theory generally, ${ }^{22}$ or if one believes that contract law expresses a plurality of values, ${ }^{23}$ then contract theory will offer little to no guidance on the moral obligation question. ${ }^{24}$

\section{CONSENT AND OBLIGATION}

The connection between consent and contract law is complicated. On one hand, the idea (or ideal) of "freedom of contract" - that one has only those contractual duties one has chosen - is central to modern contract law thinking. On the other hand, we are all aware that the level of consent in a large percentage of contracts is far from optimal.

21 On consent, see, e.g., Franklin G. Miller \& Alan Wertheimer (eds), The Ethics of Consent: Theory and Practice (Oxford, 2010); Andreas Mûller \& Peter Schaber (eds.), The Routledge Handbook of the Ethics of Consent (Routledge, 2018). On promises and agreements, see, e.g., Hanoch Sheinman (ed), Promises and Agreements: Philosophical Essays (Oxford 2011); Allen Habib, "Promises" (2014), in Edward N. Zalta (ed), Stanford Encyclopedia of Philosophy <https://plato.stanford. edu/entries/promises/>

22 See, e.g., Peter A. Alces, A Theory of Contract Law: Empirical Insights and Moral Psychology (Oxford 2011) (arguing that there can be no unified and comprehensive interpretive theory of contract law).

${ }_{23}$ See, e.g., Roy Kreitner, 'On the New Pluralism in Contract Theory' (2012) 45 Suffolk University Law Review 915.

24 In this section, I have referred to theories of contract that emphasize promise, consent, reliance, and utility/efficiency, as well as pluralist and skeptical theories. I understand that this list is not comprehensive, as it leaves out, among others, reliance-based theories, property theories, will theories, and civil recourse theories. I intend no dismissal of those approaches by not mentioning them in the main text of the section. 
THE MORAL OBLIGATION TO PERFORM CONTRACTS...

If one views full (or "perfect") consent as a combination of full information, reasonable alternatives, and no coercion, it is easy to see that most contracting (especially by those with less power: most consumers, employees, and tenants, and many commercial parties as well) falls far short. In contracts today, one or both parties may lack full information, and one or both parties may lack reasonable alternatives (e.g., because of economic necessity or because all available vendors provide the same terms).

For the most extreme failures of consent, American contract law allows a doctrinal response: agreements that are the product of certain forms of duress, misrepresentation, and mistake, can be rescinded by the party victimized. ${ }^{25}$ However, these are only the most egregious cases, and many types of less than optimal consent will evoke no doctrinal defenses to enforcement of the agreement. There are, to be sure, a small number of doctrinal questions for which lesser showings of defective consent might be relevant, but these are few and of less significance. The best example may be how a court may refuse to grant specific performance in response to a breach of contract, if the court believes that the party seeking the order has overreached. ${ }^{26}$

At what point does defective consent defeat any moral obligation one might have to perform? Consider one parameter along which consent is generally defective. In many of our agreements, we do not have reasonable alternatives. In this sense, we have no choice but to accept certain terms. For example: I may need a job, desperately, to support my family, pay the rent, and obtain adequate health insurance, but all the available jobs in my community for my skill level pay the same wages, contain the same mandatory arbitration provision (with class-action waivers), and contain the same non-compete clauses. Or, a different example: having a cell phone may be a nearnecessity for my work and for everyday life, but the contracts for all

25 See, e.g., Restatement (Second) of Contract $\S \S 151-177$ (1981).

26 In a way, this is just a specific instance of the general attitude within equity, whereby parties seeking an equitable remedy must come in "with clean hands" (and that one must "do equity to get equity"). See E. Allan Farnsworth, Contracts (4th ed., Aspen 2004), §12.4, at 741-742. 
the cell phone providers may contain the same limitation of liability and warranty provisions, and comparable choice of law and choice of forum provisions.

Yet, even where there is no real choice about certain provisions, and even where there are good arguments that the terms are unfair (while falling short of "shock the conscious" or "egregiously unfair"), one might hesitate to say that this is sufficient to undermine a moral obligation to perform one's contracts. ${ }^{27}$ After all, if consent significantly below the optimal were enough to remove the moral obligation to perform, this might mean that there is no such obligation for the vast majority of the agreements we enter as consumers, employees, tenants, etc. Is that not, then, a reductio ad absurdum of this line of analysis?

Not necessarily. Again to borrow the analogy with whether there is a moral obligation to obey the law, a number of theorists who doubt that there is a general (presumptive) moral obligation, argue that this conclusion, if true, would not lead to anarchy, even if believed by most people. The argument is that most people would still follow most of the (more important) laws most of the time, in part because those laws tend to track and pre-existing moral obligations, and in part because we have prudential reasons to avoid legal sanctions (and the reputation of being a "law-breaker"). ${ }^{28}$ Similarly, people will keep their contracts most of the time, just as they will obey the law most of the time, even if they do not think they have a general moral obligation to do so. There may be individual contracts one believes one has a moral obligation to keep (perhaps because one has been treated well or because the other party is reasonably relying on one's keeping the agreement). Additionally, one might have ample prudential reasons to perform: not wanting to be sued (with all the trouble and expense that entails), wanting to have the reputation of someone who performs one's contracts, and so on.

27 Here and elsewhere, if one did not believe that there is an initial or presumptive obligation to obey, then talk of erasing or undermining that obligation would obviously be out of place.

28 See Smith, supra note 2, at 969. 
A more substantive response would be the mere lack of (reasonable) alternatives, without more, is not sufficient to remove or reduce one's moral obligations. If the terms are reasonable, that fact that one had little choice in accepting them need not be morally problematic, even if it is far from ideal. What arguably raises more serious moral problems are certain kinds of provisions in standard forms: provisions buried deep in the contract, with language almost impossible for non-lawyers (and many lawyers) to understand, terms not brought to the attention of the party being presented with the form, and the content is substantively one-sided and unreasonable.

Karl Llewellyn, when discussing standard forms 60 years ago, argued that parties consented expressly to the main, dickered terms, and offered "blanket assent" to all "not unreasonable" terms hidden in the fine print. ${ }^{29}$ However, what of terms that are unreasonable (and not brought to the attention of the other party)? There would be a significant argument that one has not really consented to such terms, and that one would, in any event, not have a moral obligation to comply with such provisions.

Two matters to note, briefly, about this last argument. First (and perhaps obviously), good-faith observers can differ as to what counts as a "reasonable" or an "unreasonable" term. One salient example: many people use the cross-collateral provision in sales of goods made by Walker-Thomas Furniture (detailed in a well-known case) as a paradigm of an "unconscionable" term, ${ }^{30}$ while Richard Epstein offers a strong argument that such provisions were in fact eminently reasonable, given the high credit risk of the customers of that store. ${ }^{31}$ Of course, we should not be surprised by the existence of controversy surrounding moral judgments. Secondly, there is a question of whether sufficiently express consent would alter the

29 Karl N. Llewellyn, The Common Law Tradition: Deciding Appeals 362-371 (Little Brown 1960). More recently a similar position was endorsed by Randy Barnett. Randy E. Barnett, 'Consenting to Form Contracts' (2002) 71 Fordham Law Review 627-645

30 Williams v. Walker-Thomas Furniture, 350 F.2d 445 (D.C. Cir. 1965).

31 Richard A. Epstein, "Unconscionability: A Critical Reappraisal" (1975) 18 Journal of Law and Economics 295, 306-308 
evaluation. What if a (concededly) unreasonable term had been expressly brought to the attention of the party being presented with the standard form, the meaning and implications of that term clearly explained, and that party initialed the provision? Would that always (sometimes?, never?) be enough to create a moral obligation to comply with the term? This Part is, after all, about the significance of consent: how its absence or defects in it might affect our moral obligations. It is worth asking the inverse question: to what extent (relatively) express or full consent can overcome moral objections.

\section{Corrective Justice, Compensation And Distributive Justice}

A number of theorists have constructed theories of tort law that are centered on corrective justice. ${ }^{32}$ It is less common to see theories of contract law foreground corrective justice, but there is no question that corrective justice (or something like it) is a central element of contract law. Breach of contract is essentially an argument by one party to a contract that he or she has been harmed by the other party, and that the court should order some remedial action (payment of money damages or, less commonly, an order to perform) that will correct the harm, or at least lessen it.

Even if one rejects a corrective justice view of contract law (perhaps preferring what is considered the diametrically opposed view, based on efficiency or utilitarianism), it remains the case that contracts involve promises of performance (whether doing an action, payment of money, transfer of real or intellectual property or some other consideration), and contract law promises orders to pay compensatory damages if parties fail to do whatever they promised. I want to focus on the obligations - whether to perform or to payand consider them in relation to other duties and other actual or potential harms.

32 See, e.g., Stephen Perry, "Tort Law," in Dennis Patterson (ed), A Companion to Philosophy of Law and Legal Theory (2nd ed., Wiley Blackwell 2010), 64-89 at 81-88 (summarizing corrective justice and rights-based theories of tort law). 
THE MORAL OBLIGATION TO PERFORM CONTRACTS...

One question that has arisen in connection with tort law, and has relevance for contract law as well, is how we should treat the relationship between distributive justice and corrective justice. ${ }^{33}$ Distributive justice, of course, is the justice in the distribution of benefits and burdens in society. By many accounts, ours is a society of significant distributive injustice. This is not the place to debate the merits of this conclusion, but let us accept it as true for the purpose of the present discussion. Would that injustice ever affect claims under corrective justice: specifically, would the obligation to compensate be affected if people who have far less than they should (due to unjust discrimination, oppression, lack of opportunity, etc.) cause damage through a negligent or intentional action against people who have far more than they should (for comparably unjust and unjustifiable reasons), or when the oppressed breach a contract with their oppressors?

In the abstract, considerations of corrective justice seem to be "independent" of considerations of distributive justice. However, the "folk justice" held by many is that it may be acceptable to lie, cheat, or steal when one is dealing with those who have wealth or power grounded on injustice - large and evil corporations, etc. The notion that the unfortunate and powerless should be favored in any conflict with the fortunate and powerful is a common instinct; it is perhaps noteworthy that the Bible warns judges equally against favoring the poor and against favoring the powerful. ${ }^{34}$

For the present inquiry: does it affect the analysis of the moral obligation to perform one's contracts if the parties to the agreement are themselves in an unjust relationship (e.g. an exploitative employment relationship), or if they have vastly different resources in part because of past and present unjust social practices? There are, of course, some forms of exploitation and bad behavior that American contract law responds to directly, where the behavior occurs in the formation of the agreement or in its performance. As already noted, certain forms of misrepresentation, duress, and undue influence can

33 See, e.g., Jules L. Coleman, Risks and Wrongs (Cambridge 1992), pp. 350-354.

34 Leviticus 19:15: "Do not pervert justice; do not show partiality to the poor or favoritism to the great, but judge your neighbor fairly" (New International Version). 
be grounds for rescinding an agreement. ${ }^{35}$ An agreement (or term in an agreement) sufficiently unfair on both substantive and procedural grounds can be invalidated under the doctrine of unconscionability. ${ }^{36}$ And certain forms of advantage-taking in the performance of an agreement will constitute a breach of the implied covenant of good faith (and thus a breach of contract). ${ }^{37}$ Additionally, as noted above, there are some forms of overreaching that, though they will not ground a claim of rescission, may be the basis for denying equitable remedies (e.g., denying a claim for specific performance) ${ }^{38}$

However, all of those doctrines, collectively, leave a lot of room for exploitation in the agreement itself or in the relationship (employment, landlord-tenant, franchisor, consumer, etc.) within which the agreement occurs. If one's employer (or the employer's agents) treats one very badly at work, at some point does one's obligation to keep one's contractual obligations to the company cease, or at least alter? Again, this is one of those situations where common folk understanding likely diverges from the view of ethicists. There is a common (though, of course, not universal) view that what one owes a bad employer is significantly less than complete compliance with one's employment-contract duties.

Consider an analogy: under the law in many places, A's financial obligation to B under one transaction can be "set off" against B's obligation to A under a second transaction. There is no point imposing an obligation to pay a large sum in one direction, if a comparably large, or even larger, obligation to pay is due in the other direction. It is better that the two be combined for a smaller sum to be paid in the appropriate direction, which takes into account both obligations. ${ }^{39}$ One might argue that the folk thinking is comparable with contracts amid unjust relationships: that one can take into account another's

35 See supra note 26.

36 See, e.g., Uniform Commercial Code § 2-302; Restatement (Second) of Contracts $\S 208$.

37 See Farnsworth, supra note 27, §7.17, at 488-500.

38 See supra note 27.

39 See, e.g., Matter of Midland Ins. Co., 79 N.Y.2d 253, 590 N.E.2d 1186, 582 N.Y.S.2d 58 (1992) (reinsurer could offset money owed to insolvent insurer against amounts insurer owed under separate contracts). 
THE MORAL OBLIGATION TO PERFORM CONTRACTS...

wrongful behavior in "adjusting" what one owes that person or entity under an agreement.

\section{KEEPING ONE'S CONTRACTS}

When one speaks of a moral obligation to perform, what is meant here by performance? There is an obvious sense that one performs one's contract when one does the action one has promised to do: to paint the outside walls of a house, to sing a particular role in an opera on a certain night, or to pay for a service after it has been completed or a good after it has been delivered. A combination of the terms of an agreement and the doctrinal rules may indicate that one's duty to do a promised performance may be suspended or ended by the failure of the other contractual party to perform adequately or at all, ${ }^{40}$ but the present discussion will focus on circumstances where performance has not been suspended or ended in this way.

There is a tradition that views contracts as a kind of option: that the promisor should be understood as having a choice between performing the action promised and paying a certain amount of damages. This view goes back to Oliver Wendell Holmes, ${ }^{41}$ and has been more recently championed by some law and economics theorists. ${ }^{42}$ Under this approach, all contracts become a kind of "pay or play" agreement.

The question, thus, is whether (other things being equal ${ }^{43}$ ) one's moral obligation is properly focused on the promised performance,

40 See, e.g., Restatement (Second) of Contracts $§ 237$.

41 "The duty to keep a contract at common law means a prediction that you must pay damages if you do not keep it -- and nothing else". Oliver Wendell Holmes, "The Path of the Law", (1897) 10 Harvard Law Review 457, 462. Also: "The only universal consequence of a legally binding promise is, that the law makes the promisor pay damages if the promised event does not come to pass". Oliver Wendell Holmes, The Common Law 236 (Mark DeWolfe Howe, ed., 1963) (1881).

42 See, e.g., Richard A. Posner, Economic Analysis of Law $\$ 4.16$, at 152-54 (9th ed., 2014).

43 In particular, bracketing off situations where here may be specific/contextual countervailing moral considerations, e.g., where the promised performance involves an evil act (e.g., a promise to kill someone). 
or instead on either doing the promised performance or paying damages. If the former, then breach of contract will frequently, perhaps presumptively, be immoral; if the latter, then breach of contract is never, on its own, immoral, at least where one promptly pays the appropriate level of damages. ${ }^{44}$ As to the latter position, it might still be argued that it can be immoral to force the other party to sue for damages - thereby suffering significant delays, uncertainty about recovery, and significant attorney's fees. ${ }^{45}$

Certainly most people equate keeping a contract (like "keeping a promise") with performing as stated in the agreement, and do not view prompt payment of damages for non-performance as equivalent. (Just as few would see as equivalent, (a) doing what one promised, and (b) apologizing promptly and sincerely for not doing what one promised. ${ }^{46}$ ) There is a stubborn intuition that performance is the primary objective of contracts, however much the remedial structure of (American) contract law might support the equivalence of performance and payment-for-nonperformance. ${ }^{47}$

44 Cf. Steven Shavell, "Is Breach of Contract Immoral?," 56 Emory Law Journal 439 (2006); Seana Shiffrin, 'Could Breach of Contract Be Immoral?', (2009) 107 Michigan Law Review 1551 [hereinafter, Shiffrin, "Immoral”]; Steven Shavell, 'Why Breach of Contract May Not Be Immoral Given the Incompleteness of Contracts', (2009) 107 Michigan Law Review 1569.

45 Those who write with approval about "efficient breach" often seem to ignore the way that "breach" in practice is far from "efficient," especially in the costs it imposes on the non-breaching party.

46 It may be that the appropriate remedial response to not keeping a promised performance is to offer a performance as close to that as possible (taking the children to the beach tomorrow when one is unable to do it today). See, e.g., John Gardner, "What is Tort Law For? Part 1: The Place of Corrective Justice", (2011) 30 Law and Philosophy 1, 28-29. However, the basic point remains: one usually equates "keeping one's promise" with the primary promise, not the secondary or remedial promise.

47 See, e.g., Shiffrin, "Immoral," supra note 45; see also Uniform Commercial Code $\S 2-609$, Comment 1 ("the essential purpose of a contract between commercial men is actual performance and they do not bargain merely for a promise, or for a promise plus the right to win a law suit"). 
THE MORAL OBLIGATION TO PERFORM CONTRACTS...

\section{CONCLUSION}

Does one have an obligation to keep one's contracts? For many people, the initial inclination would be to answer "yes," based on the strong association of contracts and promises, combined with the belief that, other things being equal, one should keep one's promises. A closer examination of the question of the moral obligation to keep one's contracts, however, raises complications and doubts.

First, many have questioned the connection between contract and promises, arguing that contracts and contract law are best understood in some other way (e.g., as being about consent/autonomy or about efficiency/utility). Second, many are inclined to think that our duty to keep our agreements varies with how far the decision to enter the agreement deviated from optimal consent, or with facts about the fairness of the background relationship and society generally.

It seems likely (and not terribly surprising) that one's obligation to keep a contract will vary with its circumstances. Injustice in society, in the underlying relationship, in the negotiation of the agreement, or in the agreement's terms would work against any such moral obligation. If this is right, then the starting point of discussions about the moral obligation to keep contracts varies from the starting point of discussions about the moral obligation to obey the law. On the latter topic, for a long time it was assumed that, at least for generally just legal systems, a moral obligation applied equally to all laws, though one might then argue about the defeasibility of that obligation in particular cases. With contracts, people seem less inclined to assume that all contracts bind equally (or, as they say regarding legal rules and commands, in a "content-independent way"48).

There remain questions of what the content of the obligation to keep one's contract would be, assuming that there is one. Most of us would assume that it is an obligation actually to perform (unless there are good reasons not to), but some would argue merely for an obligation to perform or pay damages. Though the prompt pay-

48 See, e.g., H. L. A. Hart, Essays on Bentham 254-255 (Oxford 1982) (on laws and commands as "content independent reasons"). 
ment of damages - without disputing the breach, claiming a lower amount of damages, or threatening protracted and expensive litigation- would already be a significant advance on current common commercial practices.

\section{REFERENCES}

Alces Peter A., A Theory of Contract Law: Empirical Insights and Moral Psychology (Oxford 2011).

Austin Regina, “The Black Community,' Its Lawbreakers, and a Politics of Identification', (1992) 65 Southern California Law Review 1769.

Barnett Randy E., 'Consenting to Form Contracts' (2002) 71 Fordham Law Review 627-645.

Butler Paul, 'Racially Based Jury Nullification: Black Power in the Criminal Justice System' (1995) 105 Yale Law Journal 677.

Coleman Jules L., Risks and Wrongs (Cambridge 1992) 350-354.

Edmundson William A. (ed), The Duty to Obey the Law: Selected Philosophical Readings (Rowman \& Littlefield 1999).

Ekow N. Yankah, 'Whose Burden to Bear? Privilege, Lawbreaking and Race', Criminal Law and Philosophy (forthcoming 2019), <https://link.springer.com/article/10.1007/s11572-01909503- $\mathrm{x}>$.

EPSTEIN Richard E., 'Unconscionability: A Critical Reappraisal', (1975) 18 Journal of Law and Economics, 295, 306-308.

FARnsworth Allan E., Contracts (4th ed., Aspen 2004), §12.4, at 741-742.

FINNIS John, 'Law as Co-ordination' (1989) 2 Ratio Juris 97.

Fried Charles, Contract as Promise (2nd ed., Oxford 2015).

GARDNER John, 'What is Tort Law For? Part 1: The Place of Corrective Justice', (2011) 30 Law and Philosophy 1, 28-29.

GILMORE Grant, The Death of Contract (Ronald K. L. Collins, ed., Ohio State University Press 1995). 
Habib Allen, 'Promises', in Edward N. Zalta (ed), Stanford Encyclopedia of Philosophy (2014) <https://plato.stanford.edu/entries/promises/>.

HaRT H. L. A., Essays on Bentham (Oxford 1982) 254-255.

HeATH Wellman Christopher \& Simmons A. John, Is There a Duty to Obey the Law? (Cambridge 2005).

HobBes Thomas, Leviathan (Richard Tuck, ed., Cambridge University Press 1998) [1651], ch. 20 144-145.

Hume David, Moral Philosophy (Geoffrey Sayre-McCord ed, Hackett 2006) 361-375.

Kreitner Roy, 'On the New Pluralism in Contract Theory', (2012) 45 Suffolk University Law Review 915.

Llewellyn Karl N., The Common Law Tradition: Deciding Appeals (Little Brown 1960).

Locke John, Two Treatises of Government (P. Laslett ed, Cambridge University Press, 1988 [1689]).

Miller Franklin G. \& Wertheimer Alan (eds), The Ethics of Consent: Theory and Practice (Oxford 2010).

MûLLER Andreas \& Schaber Peter (eds), The Routledge Handbook of the Ethics of Consent (Routledge 2018).

Murphy Jeffrie G., 'Hume and Kant on the Social Contract', (1978) 33 Philosophical Studies 65-79.

Perry Stepehen, 'Tort Law' in Dennis Patterson (ed), A Companion to Philosophy of Law and Legal Theory (2nd. ed., Wiley Blackwell 2010) 64-89 at 81-88.

Plato, “The Crito," 51d-e in Plato, The Dialogues of Plato (R. E. Allen trans.), vol. 1, 117-129, at 127.

Posner Richard A., Economic Analysis of Law (9th. ed., 2014) 152154.

Posner Richard A., Economic Analysis of Law 95-158 (9th ed., 2014).

RAz Joseph, Ethics in the Public Domain 325-338 (Oxford 1994). 
REGAN Donald H., 'Reasons, Authority, and the Meaning of 'Obey': Further Thoughts on Raz and Obedience to Law', (1990) 3 Canadian Journal of Law \& Jurisprudence 3, 15.

SHAVELl Steven, 'Is Breach of Contract Immoral?', (2006) 56 Emory Law Journal 439.

Shavell Steven, 'Why Breach of Contract May Not Be Immoral Given the Incompleteness of Contracts' (2009) 107 Michigan Law Review 1569.

Sheinman Hanoch (ed), Promises and Agreements: Philosophical Essays (Oxford 2011).

SHIFfrin Seana Valentine, "Is a Contract a Promise?" in Andrei MARMOR (ed), The Routledge Companion to Philosophy of Law (Routledge 2012) 241-257.

SHIfFRIN Seana, “Could Breach of Contract Be Immoral?” (2009) 107 Michigan Law Review 1551.

Smith M. B. E., "Is There a Prima Facie Obligation to Obey the Law?", (1973) 82 Yale Law Journal 950.

Tuckness Alex, "Locke’s Political Philosophy" (2016) §4, in Edward N. ZalTa (ed.), Stanford Encyclopedia of Philosophy, <https:// plato.stanford.edu/entries/locke-political/>. 